\title{
Construction Based on the Social Development Needs of the University Network Platform
}

\author{
GongYu \\ Institute of Foreign Language, Jilin Communications Polytechnic, No, 63, New Diantai \\ Street, Changchun, Jilin Province, China. \\ tracygy@163.com
}

\section{Keywords: network culture, platform construction, social needs}

\begin{abstract}
The culture of university campus network is a new form of civilization that has the characteristics of vivid form, abundant content and rapid actual effect. It's an important source of information on campus for teachers and students. It is the extension and development of campus culture in network times and plays an active role in publicity and education guidance. As one of the most active group users, college students obtain information and knowledge through the internet, while the internet has become an indispensable part of their study and life. This makes it urgent and important to strengthen the construction of network platform and virtual campus culture.

With the continuous development of modern multimedia technology, internet has become the new media after newspaper, radio broadcast and television media. As an important medium of communication, it has played a powerful influence on the college students' study, life and work. The mutual influence and promotion in campus information network and the mass modeling activities of college students form an impact in the university students' learning life. Compared with the traditional campus culture, the culture of network has some distinguishing features such as the richness of information, sharing of resources, the virtual space, interactive communication and the equality of main body behavior. University network platform provides a resources sharing, information exchange and collaborative work platform for school teaching, scientific research and management under the certain guidance of education thought and theory within the scope of university.
\end{abstract}

\section{The connotation and characteristics of network culture in universities}

With the progress of information technology, especially the advancement of network communication technology, network culture was produced and developed. It is a kind of rationalization culture with the core content of modern technology, culture, education and value. It is a carrier of computer and communication technology and has the double connotation of technology and social culture. The campus network culture is the combination of the campus culture and network culture. It is a new cultural form that takes the network as the medium and the extension and development of campus culture in the network era. Combined with network technology and the background information of campus culture environment, it forms a new campus culture that takes the teachers and students as core.

The campus network platform provide a media teaching equipment that take learning activities as a core based on the premise of network application. It provides a openness flexibility and stability education teaching management platform for teachers, students and staff. The purpose of building is to promote the development of education in universities under the supporting role of platform. As a carrier to support the development of the network platform culture in colleges and universities, it has the following features:

Interactivity. Compared with the old rigid style of one-way interaction platform, the new form of campus network platform has the feature of vivid two-way interactive interface. Compared with any former tool, it has the characteristics of fast speed, low cost and high efficiency in communication and information query.

Strong timeliness. The campus network platform was constructed from teachers and students 
daily life on campus and entertainment aspects. To get timely information, you can fully use the upload function to update content and resources.

Rich content. The network media has the characteristics of digitization and full-time transmission. It changed the way of communication from single to complex, and combined the traditional media with video, music, text, audio, images and symbols organically. The implement makes the network be a effective tool of communication between teachers and students in colleges and universities.

Openness. The mutual collision and fusion of various value orientation, ideas, religious beliefs, customs and habits formed a rich variety of college network culture around the world.

In the rapid process of informatization in university campus, the evolution of network culture is not only promotes the development of university campus culture and expand the cultural life space and coverage, but also have an impact on traditional ideas of running a school, education environment, teaching means and campus culture, and then lead to a new generation of the traditional campus culture and campus network culture. But the network culture brings the both unprecedented challenges and abundant content of courses in traditional teaching. Therefore, how to construct characteristic campus network platform has become an important subject to our higher vocational colleges.

\section{Current status of university network culture platform construction}

Boot capacity of network culture in colleges and universities. With the constant improvement of our country university network infrastructure, the campus network culture system, such as digital library, digital campus and teaching information system provides a more efficient and convenient platform for colleges and universities. But many colleges and universities learn less about the trend of the network culture and lack the knowledge of promoting the boot capacity of culture.

Imperfect supervision mechanism of network culture in colleges and universities. At present, some universities' cultural activities lack the overall knowledge of forming a specific, powerful and guaranteed supervision mechanism, and the overall development strategy of the university culture resources has not yet included.

Relative lag in network culture platform construction. At present, some colleges and universities network culture platform have insufficient points in the network characteristic, content setting, supervision and management, subsequent construction and information interaction. The content of platform is old and single; the overall conception and page design is not reasonable and the function is short of instructive standard and poor attraction.

\section{The construction of university campus network culture platform}

The hierarchy.

The purpose of constructing the university campus network platform is to optimizing the teaching and scientific research and daily life of university teachers and students by utilizing the computer network technology. We can improve availability efficiency, increase benefit and enhance the comprehensive strength of university through the integration of campus resources.

According to its function, the finished campus network can be divided into four levels, communication layer, management layer, service layer and application layer.

Communication layer. It is the most basic form of university network, including network facilities and equipment.

Management layer. It is a corresponding system that maintains the daily operation of campus, such as cartoon system.

Service layer. It is a total sum of basic content and information resources platform. Its role is to manage all kinds of network resources; it is the foundation of the whole university campus network platform.

Application layer. The application layer is built on the ahead of other three layers; it is open to user and carry all kinds of application system, including the electronic library, OA system, the 
modern network education, online player, etc.

\section{Construction content}

The campus network culture construction produced a variety of communication mode. It formed a one-to-one, one-to-many, many-to-many multidirectional communication platform. In this module, each individual can be most widely involved in the participation of campus network. A vocational mainstream communication network platform was built with the feature of ideological and political.

Information Centers. The information centers strengthen the construction of literature resources, improve the level of modern management and the development of the characteristics of professional database. Teachers can create a variety of simulation work scene according to the abundant teaching background information while students take an active part in the curriculum activities. So we can promote the students' understanding of professional knowledge and strengthen their language skills. At the same time, long-term exercise can let the students have the ability to analyze and solve problems independently. The establishment of database provides the literature resources guarantee for college construction and long-term development.

The Curriculum Center. In most of the higher vocational colleges, profession and language was separated as a normal teaching approach. The professional teachers in charge of specialized knowledge in Chinese while English application part completed by English teachers. This kind of teaching method reduced the language practice and unable to make the language and cultural education into the technical professional ability and professional level. Higher vocational campus network culture can provide diversification interactive learning platform for the teachers and students. It emphasis on matching the English application ability and professional capacity required by the industry; it takes the "target circumstances" as the starting point of teaching. The teachers set up network courses on the platform, learners can choose the content of courses independently. It provides a feasible communication platform for the higher vocational college students to obtain occupational and professional language communication form effectively.

University-enterprise cooperation practices. The practical training module in University -enterprise cooperation practice create a variety of simulation training scene in using a variety of audio and video technology based on the precondition of rapid developmental network technology. It fuses the teaching environment and working environment together, fully embodies the concept of network teaching and realizes the students' professional quality education centered on demand.

Sharing-type professional teaching resource database. It includes training scheme, course standard, teaching program, electronic teaching plan, training guidance, evaluation standard, test database, video database, management of teaching materials, business related technical standards, etc. It is a multi-level, multi-functional, interactive teaching, learning and research resources service system based on the multimedia network. It provides professional learning and research platform for teaching and students internally while high-quality teaching resources open to the cooperative enterprise and the society.

Campus network is an important carrier of campus network culture. It is an important source of information on campus. In the campus cultural life, it plays an active role in publicity and education guidance. Universities should strengthen supervision and support intensity on the campus network. Higher vocational campus network culture is combined with modern vocational education elements so that the construction of higher vocational campus culture system has the new meaning. Higher vocational students have the demand for network virtual practical training environment and network has the characteristics of vivid form, abundant content and rapid actual effect, which makes it urgent and important to strengthen higher vocational campus network culture construction. ${ }^{3}$ It can effectively guide students' network behavior and increase students' comprehensive quality by applying advanced technology to construct higher vocational campus network culture platform.

The basic principle of campus network platform construction should aim at application and take the teaching resource as the core based on the network environment. ${ }^{4}$ Its construction target is to develop and utilize the digital teaching resources and improve information quality of teachers based on modern education teaching concept and information technology platform. The network virtual 
environment could prompt the teachers and students have an autonomous learning teaching pattern and improve the level of education and talent training quality.

Higher vocational campus network culture construction is a complicated engineering system which based on the characteristics of modern vocational education. Campus network is the daily interactive platform exists in the students, teachers and universities. ${ }^{5}$ In order to adapt to the development of the society, we should make an effective promotion in its form and content. Nowadays, the formation of healthy development of higher vocational campus network culture is a top priority. How to form the campus network system and construct the unique digital campus network culture environment, needs the joint efforts of all the teachers and students

\section{References}

[1] Information on http://www.harvard.edu

[2] Information on http://www.mit.edu

[3] Sun Yuhua: Research on the Campus Network Culture Construction of Higher Vocational Colleges Characterized by Modern Vocational Education, Volume 15 of Journal of LiaoNing Higher Vocational (2013).

[4] Liu Nan: Construction Based on the Social Development Needs of the University Network and Cultural Platform, submitted to East China University of Political Science and Law (2012).

[5] Shi Hongchun: The Challenges of Security Issues about Vocational College Campus Network Platform, submitted to Teaching and Training (2011). 